\title{
Visual Media Using in Subject Islamic Cultural History to Improve Learning Motivation of MTS Laboratorium Jambi Students
}

\author{
Asnawiyah \\ Madrasah Tsanawiyah (MTs) Laboratorium Jambi \\ E-mail: asnawiah533@gmail.com
}

\begin{abstract}
The aim of this research is to observe visual media using in subject Islamic Cultural History or Sejarah Kebudayaan Islam (SKI) and to increase the learning motivation of MTs Laboratorium Jambi students. The research used Classroom Action Research (CAR) which was carried out in 2 cycles. The research subjects are 20 students of class VIII MTs Laboratorium Jambi. The data technique was carried out through observation and questionnaires. The data analysis technique is a qualitative descriptive analysis with a proportion formula. The results of the study are obtained from the teacher activity observation sheet in cycle 1 with an average proportion formula of $80.76 \%$, and in cycle II an increase in the average proportion value of 92.30\% (very good) and the results of processing student motivation questionnaire data. in the subject of Islamic cultural history (SKI) using visual media in the first cycle it reached $87 \%$ and in the second cycle increased $96.5 \%$ including in the very high category. Thus, the use of visual media can increase student motivation at MTs Laboratorium Jambi.
\end{abstract}

Keywords: visual media, learning motivation, Islamic cultural history subject.

\begin{abstract}
Abstrak: Penelitian ini bertujuan mengetahui penggunaan media visual dalam mata pelajaran Sejarah Kebudayaan Islam (SKI) dan peningkatan motivasi belajar siswa MTs Laboratorium Jambi. Penelitian menggunakan metode Penelitian Tindakan Kelas (PTK) yang dilaksanakan sebanyak 2 siklus. Subjek penelitian adalah siswa kelas VIII MTs Laboratorium Jambi sebanyak 20 siswa. Teknik pengumpulan data dilakukan melalui observasi dan angket. Teknik analisis data adalah analisis deskriptif kualitatif dengan rumus persentase. Hasil penelitian yang diperoleh dari lembar observasi aktifitas guru pada siklus 1 dengan rumus persentase rata-rata $80,76 \%$, dan pada siklus II mengalami peningkatan dengan nilai persentase ratarata $92,30 \%$ (sangat baik) dan hasil dari pengolahan data angket motivasi siswa pada mata pelajaran sejarah kebudayaan Islam (SKI) dengan menggunakan media visual pada siklus I mencapai $87 \%$ dan pada siklus II meningkat meningkat $96,5 \%$ termasuk dalam katagori sangat tinggi. Dengan demikian, penggunaan media visual dapat meningkatkan motivasi belajar siswa pada MTs Laboratorium Jambi.

Kata-kata kunci: media visual, motivasi belajar, pelajaran SKI.
\end{abstract}




\section{Introduction}

As a learning component, media plays an important role in learning activity. Through media teacher could improve student interest and motivation, excite learning activity, and affect student psychology. It also helps student to understand subjects, present data more interestingly and authentically. ${ }^{1}$

That opinion is based on several research results. According to Muhibbaturrahmahmedia helps teacher improving student learning motivation, behavior and personality so students diligently and actively participate in learning activity. ${ }^{2}$ In line with him is Zaki Al Fuad' research that find that the use of visual media is very important for learning process, because it can boost student motivation, create fun learning atmosphere, so the expected learning outcomes will be gratified. ${ }^{3}$

A research by Birrul Walidain also found that the use of visual media could improve student learning interest, relate learning materials to real world, and positively affect learning atmosphere because students were very happy when learning by using visual media. ${ }^{4}$ On that notes, it can be realized that using visual media for learning activity will help motivating students to learn and increasing their interest in learning and generally give positive effect to students. One of subjects taught at MTs Laboratorium Jambi is History of Islam (hereinafter refered to SKI). To teach the subject teaher use various techniques and media in order to ensure the learning process can be carried out well according to learning objectives.

However, after preobserving the class, most students were found to have poor learning motivation. This problem encouraged the researcher to try an effort that can boost student spirit in learning that is using visual media when teaching Dinasty Ayyubiyah in SKI class. The effort was hoped to be able to motivate student to learn and achieve the expected learning outcomes.

Visual media consists of two words, visual and media. Media is originated from Latin word and the plural form of medium which literally means intermediary or instrument. In other words, media is a tool to deliver learning materials and information. According to Gagne, media covers all available components in learning environment that can stimulate students to learn. Then Briggs explained media as all physical tools or instruments that can be used to present learning information and motivate

${ }^{1}$ Azhar Arsyad, Media Pembelajaran, Jakarta: Raja Grafindo Persada, 2005, p. 15-16.

2 Muhibbaturrahmah, Penggunaan Media Visual untuk peningkatan Motivasi Belajar Siswa: PTK, Pendidikan Agama Islam Fakultas Tarbiyah dan Keguruan UIN Ar - Raniry Banda Aceh, 2015, p. 54.

3 Zaki Al Fuad, Penggunaan Media Visual dalam pembelajaran SKI: PTK, Pendidikan Guru Madrasah Ibtidaiyah (PGMI) Fakultas Tarbiyah dan Keguruan UIN Ar - Raniry Banda Aceh, 2012, p. 49.

${ }^{4}$ Birrul Walidain, Pemanfaatan Media Visual dalam peningkatan hasil belajar SKI: PTK, Pendidikan Agama Islam Fakultas Tarbiyah dan Keguruan UIN Ar-Raniry Banda Aceh, 2015, p. 50. 
students to learn, for example books, cassette, film and others. ${ }^{5} \quad$ AECT (Association for Education and Communication) defines media as all forms that can be used for delivering information. While according to KUBI (an Indonesian dictionary), media is communiation facility such as , newspaper, radio, film, magazine, banner, poster, and others. ${ }^{6}$ So, media is basically all things and forms that can be exploited to deliver learning information or messages or that can support lesson delivery from teacher to students in learning activity at MTs Laboratorium Jambi.

Visual is defined as the expression of an idea or feeling in the form of pictures, writings (word and number), maps and graphs. Visual media is a media that can only be seen. It does not have sound. It relies on eyes.

The researcher limits the definition of visual media in this research as all things that can help teacher at MTs Laboratorium Jambi to transfer messages and support the delivery of SKI subject materials related to Dinasti Ayyubiyah. The visual media used by the teacher was books related to Dinasti Ayyubiyah, pictures or photos, magazines, colorful cardboard for concept map, colorful origami paper used by students to write summary of the lesson, and others.

Learning is changing. In other words, learning is an effort to change behavior. Learning will change every student. It is not only about the improvement of knowledge that a studnt has but also about improving ability, skill, pride, interest, character and adaptation. ${ }^{7}$ Motive is an effort that pushes someone to do something. It is a momentum from and inside the person to do certain activities for the sake of achieving goals. ${ }^{8}$ Learning motivation is the urge from within that pushes students to do learning activity and when it becomes higher and stronger, they become more intense to participate in learning resulting in higher learning outcomes.

Learning motivation means propulsive force from within students to learn and participate in learning activity according to guide and instruction form teachers so that the learning objectives can be achieved. ${ }^{9}$ In this research the definition of learning motivation is limited to conscious impulse from student self that move them to learn and want to do their tasks. It can be in the form of critical response on problems discussed in the class, being enthusiastic to take notes, actively asking questions if theyr do not understand, and others. When those happen, the educational purpose of MTs Laboratorium Jambi in improving student motivation can be realized.

5 Arief S. Sadiman, (dkk), Media Pendidikan: Pengertian, Pengembangan, dan Pemanfaatannya, Jakarta: RajaGrafindo Persada, 2009, p. 6.

${ }^{6}$ Asnawir dan Basyiruddin Usman, Media Pembelajaran, Jakarta: Ciputat Pers, 2002, p. 32.

7 Sadirman, Interaksi dan Motivasi Belajar Mengajar, Jakarta: RajaGrafindo Persada, 2005, p. 21.

${ }^{8}$ Sadirman, Interaksi dan Motivasi, p. 73-75.

${ }^{9}$ Made Wena, Strategi Pembelajaran Inovasi Kontemporer, Jakarta: Bumi Aksara, 2009, p. 32 .

Innovatio, Vol. XX, No. 1, January - June 2020 
Studies in the past can give a general description of this research target being dicussed in this paper. Some of the references are: First, CAR (classroom action research) by Muhibbaturrahmah, a student of Islamic Education Department of FTIK UIN in UIN Ar - Raniry Banda Aceh Year 2015 titled "Using Visual Media to Improve Student Learning Motivation". Was focus on studying SKI learning process by using media in order to improve student learning motivation. His research showed that there is better change of behavior and character of students shown by their diligence and activeness in participating in the class. ${ }^{10}$

Second, CAR by Zaki Al Fuad, a student of PGMI department of FTIK in UIN Ar - Raniry Banda Aceh Year 2012 titled "Visual Media using in SKI class". The focus is to know the importance of visual media used in teaching and learning process. The study found that the availability of the media motivated students to learn and created fun learning atmosphere, and it resulted in satisfying learning process and outcomes. ${ }^{11}$

Third, CAR by Birrul Walidain, a student of PAI department of FTIK UIN Ar-Raniry Banda Aceh Year 2015 titled "The Utilization of Visual Media in Improving SKI learning outcomes". The focus was on how the use of visual media could improve student interest in learning and relate the teaching materials with real world. The result revealed that the media gave positive effect like students enjoyed the learning. ${ }^{12}$

The three researches have similarities and differences in term of using media in learning process. The similarities are the research used visual media in SKI class to improve student learning motivation and outcomes. And the differences are scores in learning motivation and outcomes.

Sejarah (Indonesian) is rooted from Arabic word syajaratun which means tree, offspring, origin, or family tree. In English Sejarah means history. Budaya (Indonesian) is originated from Senskerta language, the plural form of buddhi (human moral and mind). Sejarah kebudayaan Islam (SKI) is a subject focus of Islamic and Moslem culture. ${ }^{13}$

SKI intorduce important events of Islamic Civilization in the past to students with the purpose of teahing students to learn the spirit of Islamic civilization. It focus on teaching and building student awareness on the importance of learning Islamic teachings, values and norms which had been taught by Allah's Apostle Muhammad sallahu 'alaihi wassalam in expanding Islam.

This research was based classromm action research procedures or CAR. Car is conducted in order to improve learning practice quality in the classroom. ${ }^{14}$ According to Suharsimi, CAR is a research conducted by

\footnotetext{
10 Muhibbaturrahmah, Penggunaan Media, 2015.

11 Zaki Al Fuad, Penggunaan Media Visual, 2012.

12 Birrul Walidain, Pemanfaatan Media Visual, 2015.

13 Gitono, Buku Ajar Acuan Pengayaan Sejarah Kebudayaan Islam Untuk MTs, Jawa Tengah: Candhik Ayu, 2008, p. 3.

14 Suharsimi Arikunto, Penelitian Tindakan Kelas, Jakarta: Bumi Aksara, 2006, p. 58.
} 
teacher in his/her own classroom with the focus on improving and perfecting learning practice and process. ${ }^{15}$

The purpose of the research is to improve the learning practice continuesly. So basically, CAR is conducted in cycles until teacher achieves expected results.

Every cycle in classroom action research follows the following steps:

1. Planning

At this phase, a researcher plans the activities to be conducted in the classroom. The planning includes:

a. Deciding lessons to be taught;

b. Developing a lesson plan (RPP);

c. Making instrument to observe teacher activity in the classroom;

d. Making questionnaire of student motivation in learning activity.

2. Action

At this phase, teacher or researcher teaches and collects data. The data will be used to find problems and weaknesses so that the teacher can improve the lesson plan. This is a way to improve behavior and character to be a professional teacher.

3. Observation

Observation is conducted in collaboration with an observer. While teacher is teaching an observer will observe and write the observation data on an observation sheet. The purpose is to know, record and document all information, data or indicators from the process of teaching and achieved results. Teacher is observing student activity while an observer observes the general process and outcomes of learning. The recorded or documented data will be evaluated and used reflection.

4. Reflection

At this phase a techer will reflect on what happen in cycle I and any problem found the cycle I will be improved in lesson plan for cycle II..

The subject of this research was 20 students of Class VIII C at MTs Laboratorium Jambi, consisted of 8 female students and 12 male students/ To collect the data, the researcher used pnservation sheet and questionnaires.

Then, the data was analysed by using descriptive qualitative technique.

1. Analysis for Teacher Activity observation data

The data was from observation sheet collected during teaching-and learning process and it was calculated by using following formula:

$$
P=f / n X 100
$$

15 Suharsimi Arikunto, Prosedur Penelitian Suatu Pendidikan Praktek, Jakarta: Rineka Cipta, 2006, p. 96. 
Information :

$\mathrm{P} \quad=$ Precentage of student learning completeness

$\mathrm{f} \quad=$ Student who complete the task or activities

$\mathrm{n} \quad=$ The total of students

Id the observation was done by two people, the analysis was based on this equation:

Score $=($ Score Observer $1+$ Score Observer 2) $/ 2 \times 100 \%$ Maximum total score

According to Riduwan, the criteria for interpreting the score of observation data are:

$0 \%-20 \%=$ Very Low

$21 \%-40 \%=$ Low

$41 \%-60 \%=$ Enough

$61 \%-80 \%=$ Good

$81 \%-100 \%=$ Very Good 16

2. Analysis for student motivation questionnaire

The data of student motivation towards visual media was analysed by using following equation:

Information:

$$
P=f / n X 100
$$

$\mathrm{P}=$ Percentage of student motivation

$\mathrm{f}=$ Frequency of completed activity

$\mathrm{n}=$ The total of all activities ${ }^{17}$

The criteria for interpreting student learning motivation percentage are:

$0 \%-20 \%=$ Very low

$21 \%-40 \%=$ Low

$41 \%-60 \%=$ Enough

$61 \%-80 \%=$ High

$81 \%-100 \%=$ Very High

\section{Visual Media Using in Subject Islamic Cultural History (SKI)}

Cycle one was conducted by the researcher on Friday Masrch 1st 2019. The research was done in two cycles. The following description contains information of all acitvities and findings in the cycles.

1. Cycle I

This cycle consisted of five steps; planning, action, observation and reflection.

a. Planning

16 Riduwan, Dasar-dasar Statistik, Bandung: Alfabeta, 2013, p. 41.

${ }^{17}$ Anas Sudjono, Pengantar Statistik Pendidikan, Jakarta: Raja Gravindo Persada, 2005, p. 43. 
At this step the researcher prepared the lesson plan, materials and visual media used for teaching, Teacher observation sheet, and Stude Learning Motivation questionnaire.

b. Action

After the planning, the researcher who also acted as a teacher carried out teaching and learning process according to designed lesson plan on the first of March 2019. The actions were:

1) Teacher explained the lesson to students by using visual media.

2) Teacher divided students into four groups of four or five.

3) Teacher used the visual media.

4) Teacher evaluated the learning process.

c. Observation

The observation was done on the teacher in every meeting by two observers. They used Teacher observation sheet provided by the researcher. They observed the activity and gave score to teacher's ability in using the visual media in her teaching, starting from her classroom management to how she completed the lesson. The observers were chosen from other SKI teachers at school. The result from observation can be seen in the following table:

Table 4.8. The score from Teacher Obsevation sheets on teacher activity of teaching SKI by using Jigsaw strategy and visual media at MTs

\begin{tabular}{|c|c|c|c|c|}
\hline \multicolumn{5}{|c|}{ Laboratorium Jambi } \\
\hline \multirow[b]{2}{*}{ No } & \multirow[b]{2}{*}{ Observed Aspects } & \multicolumn{3}{|c|}{ Score } \\
\hline & & Observer 1 & Observer 2 & $\begin{array}{l}\text { Ave } \\
\text { rage }\end{array}$ \\
\hline \multirow{4}{*}{1} & $\begin{array}{l}\text { Introduction } \\
\text { a. Teacher ability in explaining the } \\
\text { purpose of learning the materials }\end{array}$ & 4 & 3 & 3,5 \\
\hline & $\begin{array}{l}\text { b. Teacher ability in connecting } \\
\text { present materials with previous } \\
\text { ones }\end{array}$ & 3 & 3 & 3 \\
\hline & $\begin{array}{l}\text { c. Teacher ability in motivating } \\
\text { students. }\end{array}$ & 3 & 4 & 3,5 \\
\hline & $\begin{array}{l}\text { d. Teacher ability in introducing the } \\
\text { lesson. }\end{array}$ & 3 & 3 & 3 \\
\hline \multirow{6}{*}{2} & $\begin{array}{l}\text { Main Activity } \\
\text { a. teacher ability in completing the } \\
\text { step of learning using visual media }\end{array}$ & 3 & 3 & 3 \\
\hline & $\begin{array}{l}\text { b. Explaining difficult terms that } \\
\text { must be known by students before } \\
\text { learning from the projector. }\end{array}$ & 3 & 3 & 3 \\
\hline & $\begin{array}{l}\text { c. Teacher ability to manage the } \\
\text { learning using visual media }\end{array}$ & 3 & 3 & 3 \\
\hline & $\begin{array}{l}\text { d. Teacher ability in explaining the } \\
\text { lesson by using the visual media. }\end{array}$ & 4 & 3 & 3,5 \\
\hline & e. The ability to use the visual media. & 4 & 4 & 4 \\
\hline & f. Appreciating students & 3 & 3 & 3 \\
\hline
\end{tabular}




\begin{tabular}{|c|l|c|c|c|}
\hline \multirow{2}{*}{3} & $\begin{array}{l}\text { Closing } \\
\text { a. } \begin{array}{l}\text { Teacher ability to direct } \\
\text { students to make summary }\end{array}\end{array}$ & 3 & 3 & 3 \\
\cline { 2 - 5 } & $\begin{array}{l}\text { b. Teacher ability to evaluate the } \\
\text { learning activity. }\end{array}$ & 3 & 3 & 3 \\
\cline { 2 - 5 } & \begin{tabular}{l} 
c. $\begin{array}{l}\text { Teacher ability in introducing } \\
\text { future topic }\end{array}$ \\
\multirow{2}{*}{ Total }
\end{tabular} & 3 & 4 & 3,5 \\
\hline & Percentage & 42 & 42 \\
\hline
\end{tabular}

Source: The result from research at MTs Laboratorium Jambi, 2019 information:

$$
\begin{array}{ll}
1 & =\text { Not good } \\
2 & =\text { Okay } \\
3 & =\text { Good } \\
4 & =\text { Very Good }
\end{array}
$$

$$
\text { Score }=\frac{(\text { Observer } 1+\text { Observer } 2) / 2 \times 100 \%}{\text { Maximum Total Score }}
$$

$$
\text { Score }=\frac{(42+42)}{52} / 2 \times 100 \%=80,76 \%
$$

The table shows a good result of teacher ability in carrying out the learning process in cycle 1 . The teacher was able to use the visual media well with the total percentage score of $80,76 \%$ (Good).

\section{d. Reflection}

According to data and analysis of cycle one, the learning process by using visual media is almost successful. Teacher ability in teacher SKI and using the media is categorized as good. However, there were some problems face by the teacher like most student cannot focus and students do not sit in order when looking at the concept map displayed by the teacher. So, there needed an improvement for the next meeting. Teacher and other two observers agreed to carry out the second cycle. The improvement are for example improve the learning stages and improve the way teacher motivate the students.

\section{Cycle II}

Cycle II was conducted on Friday March 8 2019. The cycle was following same procedures; planning, action, observation and reflection.

a. Planning

The researcher design new lesson plan by reflecting on the data founf in cycle I. The researcher also prepared concept map about the history of Dinasti Ayyubiyah. Observation sheets were given to observers and questionnaires distributed to students. 
b. Action

The actionin cycle II was basically the same as in cycle I, but there were some improvements. The materials delivered in cycle II is the continuation from cycle I.

c. Observation

The observers score the teacher on observation sheets. They observed how teacher managed and did the activity in the classroom. The observers are other SKI teachers. The observation results are displayed in the following table:

Table 4.9. The score from Teacher Obsevation sheets on teacher activity of teaching SKI by using visual media at MTs Laboratorium Jambi

\begin{tabular}{|c|c|c|c|c|}
\hline \multirow[b]{2}{*}{ No } & \multirow[b]{2}{*}{ Observed Aspects } & \multicolumn{3}{|c|}{ Score } \\
\hline & & $\begin{array}{c}\text { Observer } \\
\text { I }\end{array}$ & $\begin{array}{l}\text { Observer } \\
\text { II }\end{array}$ & $\begin{array}{c}\text { Ave } \\
\text { rag } \\
\mathrm{e}\end{array}$ \\
\hline \multirow{4}{*}{1} & $\begin{array}{l}\text { Introduction } \\
\text { a. Teacher ability in explaining the } \\
\text { purpose of learning the } \\
\text { materials } \\
\end{array}$ & 4 & 3 & 3,5 \\
\hline & $\begin{array}{l}\text { b. Teacher ability in connecting } \\
\text { present materials with previous } \\
\text { ones }\end{array}$ & 4 & 4 & 4 \\
\hline & $\begin{array}{l}\text { c. Teacher ability in motivating } \\
\text { students. }\end{array}$ & 4 & 4 & 4 \\
\hline & $\begin{array}{l}\text { d. Teacher ability in introducing the } \\
\text { lesson. }\end{array}$ & 4 & 4 & 4 \\
\hline \multirow{6}{*}{2} & $\begin{array}{l}\text { Main Activity } \\
\text { e. teacher ability in completing the } \\
\text { step of learning using visual } \\
\text { media }\end{array}$ & 4 & 4 & 4 \\
\hline & $\begin{array}{l}\text { g. Explaining difficult terms that } \\
\text { must be known by students } \\
\text { before learning from the } \\
\text { projector. }\end{array}$ & 3 & 3 & 3 \\
\hline & $\begin{array}{l}\text { h. Teacher ability to manage the } \\
\text { learning using visual media }\end{array}$ & 4 & 4 & 4 \\
\hline & $\begin{array}{l}\text { i. Teacher ability in explaining the } \\
\text { lesson by using the visual media. }\end{array}$ & & & \\
\hline & $\begin{array}{l}\text { j. The ability to use the visual } \\
\text { media. }\end{array}$ & 4 & 4 & 4 \\
\hline & k. Appreciating students & 4 & 3 & 3,5 \\
\hline \multirow{3}{*}{3} & $\begin{array}{l}\text { Closing } \\
\text { e. Teacher ability to direct } \\
\text { students to make summary }\end{array}$ & 3 & 3 & 3 \\
\hline & $\begin{array}{l}\text { f. Teacher ability to evaluate the } \\
\text { learning activity. }\end{array}$ & 4 & 4 & 4 \\
\hline & $\begin{array}{l}\text { g. Teacher ability in introducing } \\
\text { future topic }\end{array}$ & 3 & 3 & 3 \\
\hline
\end{tabular}




\begin{tabular}{|c|c|c|c|c|}
\hline & Total & 49 & 47 & 48 \\
\hline & Percentage & & & 92, \\
& & & 30 \\
\hline
\end{tabular}

Source: The research conducted at MTs Laboratorium Jambi in 2019 Information:

1. $=$ Not Good

2. $=$ Okay

3. $=$ Good

4. $=$ Very Good

\section{Score $=($ Score observer $1+$ Score Observer 2$) / 2 \times 100 \%$ Maximum Total Score}

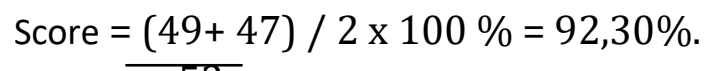
52

From the table, it can infered that teacher ability in teaching the lessok by using visual media are judged as very good and there is an improvement from previous cycle with total average percentage score of 92,30\% (very good). This also indicated that the using of visual media in cycle II improve learning atmosphere better, so it motivated student learning motivation.

\section{The Improvement of Student Learning Motivation by Using Visual Media in Subject SKI}

In order to know the improvement of student learning motivation in class VIII MTs Laboratorium Jambi on SKI subject, the researcher used questionnaire. The measurement was known after students answer the questionnaires distributed at the end of class.

The analysis of the questionnaire can be seen in the following table :

Table 4.10. The analysis of student learning motivation questionnaire on SKI subject taugh by using visual media in cycle I

\begin{tabular}{|l|l|l|l|l|l|l|l|l|l|}
\hline \multirow{2}{*}{$\begin{array}{l}\mathrm{n} \\
\mathrm{o}\end{array}$} & Question & \multicolumn{6}{|l|}{ Student Response } & \multicolumn{5}{|l|}{ Percentage (\%) } \\
\cline { 3 - 11 } & SS & S & TS & STS & SS & S & TS & STS \\
\hline 1 & $\begin{array}{l}\text { In my opinion, learning SKI by using } \\
\text { visual media is very fun }\end{array}$ & 16 & 4 & 0 & 0 & 80 & 20 & 0 & 0 \\
\hline 2 & $\begin{array}{l}\text { In opinion, I can be more focus in } \\
\text { learning by using visual media }\end{array}$ & 3 & 7 & 0 & 0 & 65 & 35 & 0 & 0 \\
\hline 3 & $\begin{array}{l}\text { In my opinion, visual media can } \\
\text { improve student motivation to learn } \\
\text { Dinasti Ayyubiyah }\end{array}$ & 0 & 12 & 4 & 4 & 0 & 60 & 20 & 20 \\
\hline 4 & $\begin{array}{l}\text { I am motivated to learn other } \\
\text { materials and topics by using visual } \\
\text { media. }\end{array}$ & 0 & 17 & 2 & 1 & 0 & 85 & 10 & 5 \\
\hline
\end{tabular}




\begin{tabular}{|c|c|c|c|c|c|c|c|c|c|}
\hline 5 & $\begin{array}{l}\text { In my opinion, the use of visualmedia } \\
\text { is suitable for learning about Dinasti } \\
\text { Ayyubiyah }\end{array}$ & 14 & 4 & 2 & 0 & 70 & 20 & 10 & 0 \\
\hline 6 & $\begin{array}{l}\text { In my opinion, the way the teacher } \\
\text { explained by using visualmedia help } \\
\text { me in understanding the materials. }\end{array}$ & 12 & 6 & 1 & 1 & 60 & 30 & 5 & 5 \\
\hline 7 & $\begin{array}{l}\text { In my opinion, using visual media } \\
\text { motivate students to be active in } \\
\text { asking question to teacher }\end{array}$ & 0 & 16 & 4 & 0 & 0 & 80 & 20 & 0 \\
\hline 8 & $\begin{array}{l}\text { I feel more motivated to learn with } \\
\text { visual media because the learning } \\
\text { atmosphere becomes more fun. }\end{array}$ & 19 & 0 & 0 & 1 & 95 & 0 & 0 & 5 \\
\hline 9 & $\begin{array}{l}\text { In my opinion, through visual media, } \\
\text { the sutdents are more focus in } \\
\text { learning. }\end{array}$ & 8 & 8 & 4 & 0 & 40 & 40 & 20 & 0 \\
\hline $\begin{array}{l}1 \\
0\end{array}$ & $\begin{array}{l}\text { In my opinion, the students are } \\
\text { motivated to lear about Dinasty } \\
\text { Ayyubiyah through visual media. }\end{array}$ & 0 & 8 & 2 & 0 & 50 & 40 & 10 & 0 \\
\hline & Total & & & & & 390 & $\begin{array}{l}48 \\
0\end{array}$ & 95 & 35 \\
\hline & Average & & & & & 39 & 48 & $\begin{array}{l}9 \\
5\end{array}$ & 3,5 \\
\hline & & & & & & \multicolumn{2}{|c|}{$87 \%$} & \multicolumn{2}{|c|}{$13 \%$} \\
\hline
\end{tabular}

\section{Information:}

SA : Strongly Agree

A : Agree

D : Disagree

SD : Strongly Disagree

The table shows the percentage of student motivation on the subject by using visual media of $87 \%$ (Very High). The interpretation is based on the criteria of student learning motivation analysis, $0 \%-20 \%=$ Very Low, $21 \%-40 \%=$ Low, $41 \%-60 \%=$ Enough, $61 \%-80 \%=$ High, and $81 \%-100 \%=$ Very High. ${ }^{18}$

The analysis of data from questionnaire in cycle II can be seen in the following table:

Table 4.11. The analysis of student learning motivation questionnaire on SKI subject taught by using visual media in Cycle II

\begin{tabular}{|l|l|l|l|l|l|l|l|l|l|}
\hline \multirow{2}{*}{$\begin{array}{l}\text { N } \\
\mathrm{o}\end{array}$} & \multirow{2}{*}{ Question } & \multicolumn{3}{|l|}{ Student Response } & \multicolumn{3}{|l|}{ Percentage (\%) } \\
\cline { 3 - 10 } & SS & S & TS & STS & SS & S & TS & STS \\
\hline 1 & $\begin{array}{l}\text { In my opinion, learning SKI by } \\
\text { using visual media is very fun }\end{array}$ & 20 & 0 & 0 & 0 & $\begin{array}{l}10 \\
0\end{array}$ & 0 & 0 & 0 \\
\hline 2 & $\begin{array}{l}\text { In opinion, I can be more focus in } \\
\text { learning by using visual media }\end{array}$ & 20 & 0 & 0 & 0 & $\begin{array}{l}10 \\
0\end{array}$ & 0 & 0 & 0 \\
\hline 3 & $\begin{array}{l}\text { In my opinion, visual media can } \\
\text { improve student motivation to }\end{array}$ & 12 & 8 & 0 & 0 & 60 & 40 & 0 & 0 \\
\hline
\end{tabular}

18 Riduwan, dasar-dasar Statistik, Bandung: Alfabeta, 2013, p. 38. 


\begin{tabular}{|c|c|c|c|c|c|c|c|c|c|}
\hline & learn Dinasti Ayyubiyah & & & & & & & & \\
\hline 4 & $\begin{array}{l}\text { I am motivated to learn other } \\
\text { materials and topics by using visual } \\
\text { media. }\end{array}$ & 0 & 16 & 3 & 1 & 0 & 80 & 15 & 5 \\
\hline 5 & $\begin{array}{l}\text { In my opinion, the use of } \\
\text { visualmedia is suitable for learning } \\
\text { about Dinasti Ayyubiyah }\end{array}$ & 20 & 0 & 0 & 0 & $\begin{array}{l}10 \\
0\end{array}$ & 0 & 0 & 0 \\
\hline 6 & $\begin{array}{l}\text { In my opinion, the way the teacher } \\
\text { explained by using visualmedia } \\
\text { help me in understanding the } \\
\text { materials. }\end{array}$ & 14 & 4 & 2 & 0 & 70 & 20 & 10 & 0 \\
\hline 7 & $\begin{array}{l}\text { In my opinion, using visual media } \\
\text { motivate students to be active in } \\
\text { asking question to teacher }\end{array}$ & 5 & 15 & 0 & 0 & 25 & 75 & 0 & 0 \\
\hline 8 & $\begin{array}{l}\text { I feel more motivated to learn with } \\
\text { visual media because the learning } \\
\text { atmosphere becomes more fun. }\end{array}$ & 19 & 0 & 0 & 1 & 95 & 0 & 0 & 5 \\
\hline 9 & $\begin{array}{l}\text { In my opinion, through visual } \\
\text { media, the sutdents are more focus } \\
\text { in learning. }\end{array}$ & 20 & 0 & 0 & 0 & $\begin{array}{l}10 \\
0\end{array}$ & 0 & 0 & 0 \\
\hline $\begin{array}{l}1 \\
0\end{array}$ & $\begin{array}{l}\text { In my opinion, the students are } \\
\text { motivated to lear about Dinasty } \\
\text { Ayyubiyah through visual media. }\end{array}$ & 0 & 20 & 0 & 0 & 0 & $\begin{array}{l}10 \\
0\end{array}$ & 0 & 0 \\
\hline & Total & & & & & $\begin{array}{l}65 \\
0 \\
\end{array}$ & $\begin{array}{l}31 \\
5\end{array}$ & 25 & 10 \\
\hline & Average & & & & & 65 & 31,5 & 2,5 & 1,0 \\
\hline & & & & & & \multicolumn{2}{|c|}{$96,5 \%$} & \multicolumn{2}{|c|}{$3,5 \%$} \\
\hline
\end{tabular}

Information:

SA : Strongly Agree

A : Agree

D : Disagree

SD : Strongly Disagree

From the table it can be inferred that student learning motivation on SKI subject being taught by using visual media in cycle II is categorized as very high. The total score of $96,5 \%$ shows that students agreed to use visual media in order to improve their learning motivation. About 3,5\% response shows that few students disagreed. This kriteria is based on the kriteria used by Riduwan. $81 \%-100 \%$ is categorized as very high, and $0 \%-20 \%$ is categorized as very low. ${ }^{19}$ 


\section{Closing}

Based on the result of the research on using visualmedia in teaching Dinasti Ayyubiyah in SKI class in Class VIII at MTs Laboratorium Jambi, It can be concluded that there is an improvement in teaching the subject by using visual media which is categorized as good. With the score of $80,76 \%$ in cycle I and become 93,30\% (Very Goog) in cycle II

There is an improvement in student learning motivation through using visual media and it is categorized as ver high. With the score of $87 \%$ in cycle I and $96,5 \%$ in cycle II.

Based on those results, some suggestions are given to SKI teachers in order to improve their student motivation to learn SKI. Visual media is very suitable to be used in SKI class. Other than improving student learning motivation, it also helps students to easily understand the material in the class. It can be One of useful medias for teaching SKI in Islamic schools in general and in Class VIII MTs Laboratorium Jambi specifically. However, the success of the teaching also depends on how good teacher choose and decide the correct materials or topics to be presented through visual media.

\section{Bibliography}

Anas Sudjono, Pengantar Statistik Pendidikan, Jakarta: Raja Gravindo Persada, 2005.

Arief S. Sadiman, dkk), Media Pendidikan: Pengertian, Pengembangan, dan Pemanfaatannya, Jakarta: PT RajaGrafindo Persada, 2009.

Asnawir dan Basyiruddin Usman, Media Pembelajaran, Jakarta: Ciputat Pers, 2002.

Azhar Arsyad, Media Pembelajaran, Jakarta: Raja Grafindo Persada, 2005.

Birrul Walidain, Pemanfaatan Media Visual dalam peningkatan hasil belajar SKI: PTK, Pendidikan Agama Islam Fakultas Tarbiyah dan Keguruan UIN Ar-Raniry Banda Aceh, 2015.

Gitono, Buku Ajar Acuan Pengayaan Sejarah Kebudayaan Islam Untuk MTs, Jawa Tengah: Candhik Ayu, 2008.

Made Wena, Strategi Pembelajaran Inovasi Kontemporer, Jakarta: Bumi Aksara, 2009.

Muhibbaturrahmah, Penggunaan Media Visual untuk peningkatan Motivasi Belajar Siswa: PTK, Pendidikan Agama Islam Fakultas Tarbiyah dan Keguruan UIN Ar - Raniry Banda Aceh, 2015.

Riduwan, Dasar-dasar Statistik, Bandung: Alfabeta, 2013.

Sadirman, Interaksi dan Motivasi Belajar Mengajar, Jakarta: RajaGrafindo Persada, 2005. 
Suharsimi Arikunto, Penelitian Tindakan Kelas, Jakarta: Bumi Aksara, 2006.

Suharsimi Arikunto, Prosedur Penelitian Suatu Pendidikan Praktek, Jakarta: Rineka Cipta, 2006.

Zaki Al Fuad, Penggunaan Media Visual dalam pembelajaran SKI: PTK, Pendidikan Guru Madrasah Ibtidaiyah (PGMI) Fakultas Tarbiyah dan Keguruan UIN Ar - Raniry Banda Aceh, 2012. 